\title{
The ecosystem approach and the global imperative on Toronto's Central Waterfront
}

\author{
Jennefer Laidley \\ Faculty of Environmental Studies, York University, J09 HNES, 4700 Keele Street, Toronto, Ont., \\ Canada M3J JP3
}

Available online 23 February 2007

\begin{abstract}
As one of the 'last great waterfronts' to embrace what has become a near-ubiquitous post-fordist development model, the formerly industrial lands of Toronto's Central Waterfront are currently being reshaped to provide the kinds of spaces and places that facilitate new modes of capital accumulation. In order to understand how Toronto's waterfront has come to be mobilized to accommodate the imperatives of 21 st-century global economic and spatial restructuring, this paper explores the area's recent planning history, reviewing the policies and politics of waterfront planning activities undertaken over the past twenty years. A new and novel 'ecosystem approach' to waterfront planning was adopted in Toronto in this period that allowed its proponents to resolve historical problems that had formerly impeded new forms of waterfront development. This paper demonstrates that, in so doing, the ecosystem approach - and its use by a succession of influential waterfront planning bodies and processes - set the stage for the Central Waterfront to become a key site for the elite pursuit of world city status in Toronto.
\end{abstract}

Keywords: Waterfronts, world cities, urban development, economic restructuring, ecosystem planning, urban planning, Toronto

Introduction: waterfront planning in Toronto: contradictions and connections

This paper examines the politics of planning for development on Toronto's Central Waterfront over a period of approximately 15 years. Between the late 1980 s and the early 2000s, the focus of waterfront planning activity and the rationale for its development underwent a significant shift, from the 'ecosystem approach' recommended by the Royal Commission on the Future of Toronto's Waterfront to a 'global imperative' approach currently being pursued by the Toronto Waterfront Revitalization Corporation. While on the surface these two approaches to waterfront development seem incongruous, the analysis presented in this paper demonstrates their deep political and economic con- nections in the period of transition from an industrial to a post-industrial waterfront.

In 1992, the Royal Commission on the Future of Toronto's Waterfront released its final report, entitled Regeneration, which introduced what was heralded as a new era of progressive, holistic, environmentally-based planning for Toronto's waterfront and the ecosystem of which it is a part. The 'ecosystem approach', as it was called, promised to bring together in one development model "the long-term promise of a healthy environment, economic recovery and sustainability, and maintaining a livable community" (Royal Commission on the Future of the Toronto Waterfront, 1992, pp. 16-17). Ecosystem planning, it was said, produces "more effective and creative solutions" than traditional planning due to its concentration on understanding the interactions in ecosystems, its long-term view of change, its focus on diversity, heritage, environmental capacity, flexibility, and its inclusionary mode of decision-making (Royal 
Commission on the Future of the Toronto Waterfront, 1992, pp. 77-81). Founded on the notion that "everything is connected to everything else" (Royal Commission on the Future of the Toronto Waterfront, 1990, p. 17), the ecosystem approach recognised connections between human activity and the natural world and the various impacts of environmental health and degradation on economic and social activity. Only through a reconfiguration of waterfront planning and development from within the intersection of environment, economy, and community, the ecosystem approach proclaimed, could the vision be found to "restore the health and usefulness of the waterfront" (Royal Commission on the Future of the Toronto Waterfront, 1990, p. 83).

The approach quickly gained currency. It was described in the media as "very heady stuff" (Valpy, 1990), and "the wave of the future" (Toronto Harbour Commissioners, 1992, p. 4), a revolutionary "greenprint" (Armstrong, 1992) praised by environmentalists, academics, politicians and pundits alike. The tenets of the ecosystem approach were seen in several municipal and Metro Toronto and Region Conservation Authority planning documents and the reports of the Commission on Planning and Development Reform in Ontario and the Greater Toronto Area Task Force. Some contemporaneous academic literature said that the work of the Royal Commission signalled "the emergence of an innovative approach to waterfront planning and policymaking" which "placed urban waterfront planning in the novel context of environmental sustainability" (Goldrick and Merrens, 1996, p. 219, 220). The ecosystem approach was said to have become a requisite part of contemporary municipal planning efforts in Toronto (Suzuki, 1992) and, indeed, the work of the Royal Commission is still hailed by some as an 'exemplary' example of environmental planning (Hodge, 2003, p. 263; Hodge and Robinson, 2001, pp. 222-225).

Within 10 years, however, a new approach to waterfront planning and development had gained ascendancy. In November 1999, the federal, provincial and municipal governments announced an unprecedented co-operative plan to redevelop $46 \mathrm{~km}$ of Toronto's waterfront and, within one year, publicly committed to a $\$ 1.5$ billion investment in infrastructure that would spark a "virtuous cycle," attracting billions in private investment from the companies and people fuelling key sectors of the global economy, thereby creating jobs and, ultimately, the tax revenues necessary to fund public services (City of Toronto, 1999a, p. 7). To oversee this new vision, the three levels of government joined forces to create the Toronto Waterfront Revitalization Corporation (TWRC), a new and nominally public body whose planning and implementation work is driven by its private sector board, management team, and consultants. The TWRC's plan for waterfront development, the
Development Plan and Business Strategy, addresses and responds to many of the same problems - and indeed, proposes many of the same solutions - as the Royal Commission. However, this new vision is predominantly focused on the economic benefits which can be derived from waterfront development. More importantly, however, it positions waterfront development as a crucial and strategic competitive necessity for the economies of Toronto, the GTA and the nation in the context of 21st-century global economic restructuring. The Development Plan positions its various components, such as land use, public space, and environmental remediation, as strategic investments in "fostering economic growth and rebranding Canada" (Toronto Waterfront RevitalizationCorporation, 2002, p. 7). In order for Toronto to compete globally in the 21 st-century, this new vision implores, the waterfront must be developed in particular ways that accommodate the needs and desires of the global economy. The Toronto waterfront has become the "gateway to a new Canada" (Toronto Waterfront Revitalization Corporation, 2002, [n.p.]) and presenting Toronto's best face to the world is now paramount.

I argue in this paper that it is within the Royal Commission's 'ecosystem approach' to waterfront development and specific activities undertaken by its principle actors under its aegis that the roots of the current global vision for the waterfront can be found. While it is certainly difficult to "untangle the knot of forces behind any waterfront development" (Malone, 1997, p. 6), and while claiming to capture anything approaching the complexity of this knot of forces is disingenuous at best, I argue that the Royal Commission on the Future of the Toronto Waterfront represents a particular strategic moment in Toronto's waterfront history in which an environmental approach to development was popularised that subsequently allowed a variety of actors working in concert to contain political and economic struggle by resolving long-standing institutional and political problems. As with many other attempts to contain crisis, the resolutions to these problems created their own set of contingent circumstances which, in combination with economic and political activities occurring on a variety of scales, have resulted in the current configuration of ideological and economic imperatives driving the revitalization of Toronto's Central Waterfront.

As such, Toronto's Central Waterfront is just one of the crucial sites of a "metabolic metropolitics" (Keil and Boudreau, 2006) that has been identified in Toronto which has seen a significant neoliberalization of urban policy intertwined with the institutionalization of ecological concerns. Perhaps paradoxically, at the same time that urban entrepreneurialism and competitiveness have taken firm root in Toronto (Kipfer and Keil, 2002), an increasingly environmentally-focused politics has fundamentally shaped the city's political and policy terrain (Desfor 
and Keil, 2004; Keil and Boudreau, 2006). While these two logics seem at first blush to be ideologically and materially antagonistic, the politics of growth and the politics of the environment have become important correlates in the development politics of urban regions (Keil and Graham, 1998; While et aI., 2004). Indeed, as "urban development processes have become increasingly associated with ecological concerns" (Desfor and Keil, 2004, p. xii), a new 'green consensus' seems to have been built in Toronto that sees the city's future as fundamentally dependent on a new ecological/developmental nexus (Keil and Boudreau, 2006).

Drawing from the literature connecting the politics of nature to urban development processes (see, for example, Keil and Graham, 1998; Desfor and Keil, 2004; Swyngedouw et aI., 2005), this paper explores the construction of this green consensus in Toronto from an historical perspective centred on Toronto's Central Waterfront. I contend that waterfront planning activity in Toronto between the late 1980s and the early 2000s - the period in which an intense neoliberalization of the city's urban policy has occurred (Kipfer and Keil, 2002) - has been a major contributor to this consensus, and that the use of an 'ecosystem approach' to waterfront planning, which was popularised in the early 1990s by the Royal Commission on the Future of the Toronto Waterfront, was key to achieving this consensus. Moreover, I argue that the ecosystem approach was instrumental in resolving three historic problems that hampered Toronto's ability to reconfigure its waterfront to respond to 21 st-century economic and growth imperatives, allowing for the current global vision for the waterfront to take root and for the Central Waterfront to become a key site for the elite pursuit of world city status in Toronto. As such, it may be the case that Toronto's green consensus insofar as it relates to the politics of development - may have been achieved not as a result of Toronto's conservative elites leaving their "environmental flank unprotected from a surging environmental activism" (Keil and Boudreau, 2006, p. 41) but rather through their explicit incorporation of environmental concerns into a growth-oriented and spatially-ordered prescription for the city centred on an ostensibly ecological waterfront planning paradigm. In the Toronto case, the ecosystem approach to planning was a highly effective strategy through which the seemingly antagonistic ideological and material logics of global interurban place competition and environmentalism were reconciled, opening up the conceptual, political, and physical space necessary to allow for a post-industrial, globally-focused spatial fix.

The approach that I have taken to exploring Central Waterfront development in Toronto is historical and draws from media reports, City of Toronto Council minutes and staff reports, federal and provinciallegislative debates, and a wide range of plan- ning and policy documents from all four levels of government. I have also examined the many reports of the Royal Commission, conducted interviews with some of the key players of the period, and reviewed scholarly literature about development politics in Toronto, environmental politics in Ontario, and waterfront development and Olympic Games research worldwide.

While "urban development processes have become increasingly associated with ecological concerns" (Desfor and Keil, 2004, p. xii) it is not my intention to engage in a critique of the Royal Commission's ecosystem approach in terms of its suitability for environmental protection - that is, as an exemplar of environmental planning'. Indeed, the literature critically examining the pitfalls of ecological modernisation has already deftly demonstrated that such "win-win" approaches to urban problems subsume environmental issues under neoliberalised concerns of "efficiency, competitiveness, marketability, flexibility and development" (Keil and Desfor, 2003, p. 1; see Desfor and Keil, 2004). Rather, the following narrative illustrates the micro-processes through which the Royal Commission on the Future of the Toronto Waterfront, and its successor agency the Waterfront Revitalization Trust, acted as key agents of ecological modernization in Toronto (Desfor and Keil, 2004, p. 222; Kipfer and Keil, 2000), and highlights the ways in which recent locally-focused political struggles and economic activities, embedded within an environmental approach to urban planning and development, have influenced the processes of urban change.

\section{Waterfront development struggles in context}

By the late 1960s, with deindustrialization, industrial outmigration, and containerization on the rise, Toronto's Central Waterfront (see Figure 1) housed only a remnant of its historic industrial and port-related functions. Warehouses, scrapyards, and oil storage tanks proliferated and, though largely unrecognised at the time, soil and groundwater contamination plagued the lands. Economic and technological change had left the Central Waterfront a "terrain of availability" (Greenberg, 1996). In the ensuing two decades, the waterfront was the site of a fractious debate over which institutions of government should have primary control over planning and development, which land uses should be allowed to dominate, and what degree and type of access the public should have to both waterfront lands and the water itself. The development politics of the period can thus be characterised as being deeply concerned with three primary issues: jurisdictional

1 Nor is it my intention to criticise the work of the variety of expert consultants to the Commission, particularly in the field of environmental planning, who have been recognized as having made significant contributions to their respective fields. 


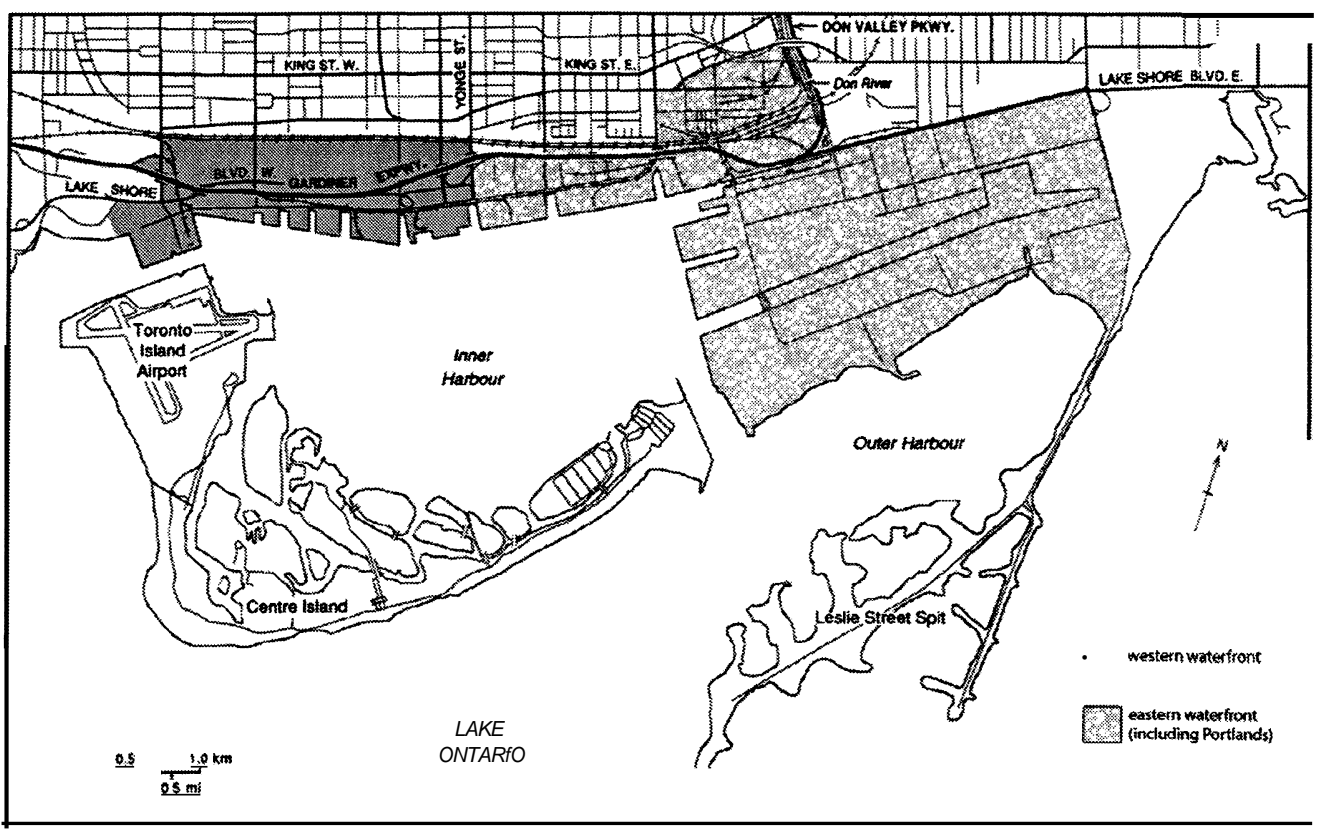

Figure 1 Toronto's Central Waterfront.

gridlock; industrial zoning; and the management of private versus public interests.

First, a patchwork quilt of government agencies, departments and bodies with overlapping and sometimes conflicting mandates held a variety of jurisdictional claims to waterfront lands. The Toronto Harbour Commissioners (THC), a federal agency constituted in 1911 as an industrial development and port-minding body, claimed jurisdictional supremacy. However, a plethora of agencies, departments, and special-purpose bodies of all four levels of government (municipal, regional, provincial and federal) held some measure of responsibility over waterfront-related issues. Decision-making by the THC, which in this period seems to have been primarily motivated by a desire to supplement dwindling port revenues through the sale of its publiclyheld land (Desfor, 1993), led to hostility and challenges from other public bodies, most particularly the City of Toronto. The tension surrounding jurisdictional questions resulted in what was called 'jurisdictional gridlock,' which was often blamed for continuing indecision, delays and a lack of coherent development planning (Desfor, 1993).

Second, despite industry's continuing decline, the eastern waterfront remained almost exclusively zoned for industrial and port-related uses. The land-use policies of both the City of Toronto and the Metropolitan Toronto regional government staunchly supported the retention of industrial jobs and the defense of the historic role of industry in the Toronto economy. However, major mixed-use projects on the western waterfront demonstrated the growing economic potential of non-industrial uses. Vacant waterfront sites became increasingly seen as economic opportunities for the development industry, and the benefits of increasing tax revenues became increasingly difficult for local governments to ignore. In addition, a bid for the 1996 Olympic Games proposed opening up the eastern waterfront to sports and residential uses. While the bid ultimately failed, it added much to the debate over the appropriate use of waterfront lands. Moreover, public demand mounted for recreational access, and public dismay over the shape and form of mixed-use projects led to calls for firmer development guidelines, height and density restrictions, and more open space (Greenberg, 1996).

Third, the public increasingly expressed concern about what could be characterised as the privatisation of the waterfront. The publicly-held lands of the western waterfront were being privately developed for what were seen as "mainly luxury" condominium units and retail uses (Crook, 1983, p. A6). The seeming exclusivity of these developments ran directly counter to the urgent and widely acknowledged need for affordable housing in the city, as well as to calls for increased public access to the waterfront. The proliferation of private residential developments on waterfront land contributed to the sense that private profit-taking was being privileged over the public interest. ${ }^{2}$ As the first interim report of the Royal Commission stated, the public expressed

\footnotetext{
2 In this instance, the highly problematic term 'public interest' was defined in terms of accessibility to publicly-owned lands which had long been unavailable to public use. And indeed, while private interests had long been involved in guiding public planning for the waterfront (Desfor, 1993), it appeared that City Hall increasingly favoured market imperatives.
} 
considerable "dismay and anger" that "at the moment their waterfront was reappearing, it was being lost again. That instead of being joined to it, they were being further separated from it. That instead of being opened up, the waterfront was being walled off" (Royal Commission on the Future of the Toronto Waterfront, 1989a, pp. 9-10). In other words, as waterfront lands became increasingly available for new uses, market imperatives were being privileged by the state over affordable housing, better public access, and public parkland, all of which would help to restore the city's connection to the water's edge in a more equitable manner. The disjuncture between the public's interest in waterfront accessibility and affordability and a condoning of high-cost private development by the THC and the City was a matter of intense public debate.

Higher levels of the Canadian state were also making a shift toward market-based governance and a neoliberalisation of public policy. Driven by fiscal concerns, provincial policy increasingly positioned publicly-owned waterfront lands as an economic rather than environmental or recreational- resource (Ontario, 1996). Federally, the 1984 election saw Brian Mulroney's Progressive Conservative party win the largest parliamentary majority in Canadian history, indicating a significant shift toward privatisation, program rationalisation, and less government intervention in the economy (Savoie, 1994, p. 89). The federal government's 1987 Federal Land Management report, produced to determine how "to maximize the efficient provision of government services and the economic use of Federal property" (McLaughlin, 1987, p.1), was critical of federal agencies such as the THC, and concluded that "the federal government's legitimate constitutional responsibilities did not include being in the 'land business"' (Desfor, 1993, p.174). Media reports at the time speculated that all federal lands were about to be sold, with the lion's share of benefits accruing to private developers.

By the mid-1980s, the waterfront had become a territorial, economic, and political battleground. Action was required to resolve jurisdictional problems, competing land-use visions, and concerns about waterfront privatisation, and to quell the chorus of widespread and increasingly vocal public discontent.

\section{The royal commission: a mandate for change}

In 1988, the federal government responded by creating the Royal Commission on the Future of the Toronto Waterfront ${ }^{3}$ and giving it a broad mandate to "inquire into and to make recommendations regarding the future of the Toronto Waterfront" (Royal Commission on the Future of the Toronto Water-

\footnotetext{
3 A Royal Commission is the highest level of government inquiry at the federal level of the Canadian state. Recommendations made by a Royal Commission are not, however, binding on government.
}

front, 1989a, p. v). Former Toronto mayor David Crombie, whose involvement in Toronto's civic reform movement of the late 1960s and early 1970s had provided him a reputation as an advocate for 'reasonable' development, was appointed sole Commissioner. The Commission's mandate indicated that jurisdictional and land use issues would be major areas of consideration, and that creating agreement around waterfront development was a primary goal. And while the mandate of the Commission did not explicitly include examining the role of private interests in waterfront development, Crombie declared early on that resolution of waterfront problems hinged on "the willingness of public authorities and private interests to recognise the needs of others and the value of concerted action" (Toronto Harbour Commissioners, 1989, p. 2). An environmental focus was also written into the Commission's mandate and, while not initially central, the environment would rapidly become key to the Commission's work.

\section{The ecosystem approach: creating an environment for} development

The first year of the Commission's mandate was largely devoted to addressing jurisdictional infighting; however, its hearings on these issues were dominated, the Commission stated, by environmental concerns: "almost everyone urged the Commission to spend more time on environmental matters and to view the Commission's mandate through the prism of environmental responsibility" (Royal Commission on the Future of the Toronto Waterfront, 1989a, p. 12). Indeed, a 1989 Environics poll showed that the environment was Canadians' top concern (Adams and Neuman, 2006). Although essentially a footnote, the Commission's first Interim Report of 1989 recommended the creation of a 'green strategy' for the entire watershed in order to protect the environment while promoting development (Royal Commission on the Future of the Toronto Waterfront, 1989a, p. 195; see Goldrick and Merrens, 1996). One short year later, however, the environment had become the dominant theme and a variety of experts in many environmental fields had been brought on board as advisors to' the Commission. By the time of the Commission's second interim report in 1990, the initially peripheral 'green strategy' had become the foundational paradigm for the Commission, which it called an 'ecosystem approach' to waterfront planning.

The Commission's ecosystem approach focused on appreciating "links and relationships" and preserving "the integrity, quality, productivity, dignity, and well-being of the ecosystem," emphasising the notion that "everything is connected to everything else" (Barrett, 1991, p. 37; Royal Commission on the Future of the Toronto Waterfront, 1990, p. 17). Cities, it proposed, should be understood as natural 
ecosystems within which environmental, economic, and community concerns are interrelated and mutually constitutive. Waterfront-related studies and plans, therefore, should "be undertaken in an integrated way, examining the links among economic, social, and environmental matters" (Royal Commission on the Future of the Toronto Waterfront, 1992, p.34).

It is significant that the Commission's adoption of the ecosystem approach occurred during a period of intense public interest in environmental issues. This period has been characterised as a second 'green wave' in Canada that peaked in 1989 and saw not only an increase in public stewardship activity but also an intense level of public pressure directed at governments, which in response enacted a variety of new environment-related policy directions and strengthened environmental legislation, programs and enforcement (Hartmann, 1998; Krajnc, 2000; McKenzie, 2002). The Commission's emphasis on environmentalism can be seen as a similar response. The adoption of the ecosystem approach was as much a strategy that responded to public sentiment as led it, and served to generate support for waterfront development from among a broad constituency - including environmentalists, a group traditionally opposed to the imperatives and consequences of growth.

Key to the Commission's ecosystem approach was the notion that "a good quality of life and economic development cannot be sustained in an ecologically deteriorating environment" (Royal Commission on the Future of the Toronto Waterfront, 1990, p. 156). The environment - or rather, its health - was functionally positioned as a prerequisite to economic growth, and thus environmental regeneration became a primary rationale for waterfront development. As McKenzie notes, the second wave of environmentalism took a conciliatory approach to capital, actively pursuing concepts such as "market-based incentive, demand side management, technological optimism, non-adversarial dialogue, and regulatory flexibility" in its problem-solving efforts (McKenzie, 2002, p. 65). As such, the environment-development nexus of the ecosystem approach dovetailed well with prevailing sentiments.

The ecosystem approach was thus able to address much more than the environmental concerns implied by its name. As Harvey notes, "the contemporary battleground over words like 'nature' and 'environment' is a leading edge of political conflict" because these words "convey a commonality and universality of concern that can all too easily be captured by particularist politics" (Harvey, 1996a, p. 118). In this case, the universality of the ecosystem approach helped to quell political conflict, giving all concerned an acceptable and defensible foundation upon which to pursue their various interests. Indeed, a large part of the Commission's success lay in the ability of both the term and the approach to encompass a range of meanings. And under the con- ceptual aegis of the ecosystem approach, the Commission took a number of steps which brought a measure of resolution to the three primary issues in the development politics of the period, which together were effectively preventing a politically acceptable, publicly supported, and co-ordinated plan for waterfront redevelopment.

\section{Moving toward resolution: the ecosystem approach and jurisdictional gridlock}

The Commission's initial steps toward resolving gridlock lay in ending the THC's hold over waterfront development. The Commission insisted that in part as a consequence of the agency's inability to both fully develop the industrial potential of its lands and protect the lands from environmental degradation - the THC's development powers be separated from its port management role. Following heated battles (Desfor, 1993), action was taken which restricted the THC's mandate to port-related functions, reduced the port itself from 486 hectares to approximately forty, and transferred the remaining land from the THC to the City of Toronto's fledgling economic development body.

Second, the Commission created a new model for decision-making, one which would better accommodate the forms and processes of nature. The Commission stated that an ecosystem approach necessitated recognising that "ecological processes... rarely conform to political boundaries, such as city limits" (Royal Commission on the Future of the Toronto Waterfront, 1992, p. 41) and thus planning would have to be "based on natural geographic units - such as watersheds - rather than on political boundaries" (Royal Commission on the Future of the Toronto Waterfront, 1990, p. 20). This conceptual expansion of the waterfront's territorial purchase allowed for an expansion of the scope and scale of the issues and jurisdictions involved and a subsumption of political boundaries under a larger geopolitical unit, the watershed. This green rescaling of the waterfront served to focus the various political jurisdictions away from turf wars and petty jealousies and onto both larger and, given the environmental tenor of the times, more politically expedient concerns.

The Commission thus subsequently adopted a 'stakeholder roundtable' model, based on the broader conceptual territory of the ecosystem approach. The roundtable model was perhaps the Commission's greatest strength, both in terms of addressing jurisdictional gridlock as well as in forging a new consensus around waterfront development. Indeed, the Commission's work groups, committees, and public consultations brought together "agencies, organizations, levels of government, and individuals - in some cases, those that had never worked with or even met each other before" (Royal Commission on the Future of the Toronto Waterfront, 1992, p. 46), from a wide range of fields and interests, both public 
and private. This broad inclusivity - coupled with the politically powerful environmentalism reflected in the ecosystem approach - assisted in galvanising support for waterfront development from all levels of government as well as many other groups and sectors.

\section{The ecosystem approach and industrial zoning}

The convergence of economy and environment in the ecosystem approach facilitated consideration of a broad range of land uses on the waterfront, which were deemed necessary for achieving both economic and social sustainability. A variety of the Commission's stakeholder roundtables explicitly challenged local industrial retention policies as constituting an inadequate use of the land's inherent value, and proposed opening up the waterfront to a variety of land uses, most particularly the increasingly lucrative mixed-use modeI. ${ }^{4}$

The Commission not only agreed that "an attractive and vibrant waterfront supports a range of uses" (Royal Commission on the Future of the Toronto Waterfront, 1990, p. 59), but also rationalized residential development on the waterfront as a defence of the environment. The Commission noted that suburbanization and land use segregation had resulted in a host of environmental and quality of life problems, such as increased smog, commuting times, fossil fuel consumption, and the loss of natural areas and farmland. An increase in density in Toronto's core could ameliorate these problems, and thus residential development on the waterfront was deemed vital to improving environmental quality in the entire region (Royal Commission on the Future of the Toronto Waterfront, 1992, p. 320). The ecosystem approach thus allowed waterfront development to be reconceived as a response to environmental problems and a benefit to urban quality of life. ${ }^{5}$

Improving environmental well-being was also the justification for allowing and promoting new types of industrial activity on the waterfront. Partly as a defence of industrial employment and partly in response to the growth of new economic sectors, the Commission saw the waterfront as a site for "second-generation industry," which it lauded as more flexible, more globally competitive and, importantly, more 'green' (Royal Commission on the Future of the Toronto Waterfront, 1989a, p. 114; Royal Commission on the Future of the Toronto Waterfront 1989b, p. 89). Indeed, the Commission explicitly encouraged allowing space for emerging industries focused on products and technologies "geared to

\footnotetext{
4 See Grant (2002) for an examination of mixed-use development in Canada, its meanings, objectives, and strategies, and its entrenchment in Canadian planning practice, in part rationalized by environmental imperatives.

5 See Bunce (2004) for an examination of this strategy of ecological modernisation in the City of Toronto's 2002 Official Plan.
}

environmental protection and improvement" (Royal Commission on the Future of the Toronto Waterfront, 1989a, p. 115). Environmental degradation was thus increasingly perceived to hold the potential for economic benefit and steps taken to realise this benefit were characterised as the productive activity of the future, allowing new industries "to profit quite literally - from past mistakes" (Royal Commission on the Future of the Toronto Waterfront 1990, p. 142).

The environmental emphasis of the ecosystem approach also helped to undermine the exclusivity of industrial zoning through allowing for a response to widespread calls for recreational opportunities and better public access. In doing so, the Commission recommended the creation of a Waterfront Trail across the entire length of the waterfront, which would not only provide further opportunities for water's edge uses, but would also connect existing recreational and cultural facilities and green spaces (Reid et aI., 1989).

The Waterfront Trail was also, however, the main feature of a system of 'green infrastructure' that would act as a catalyst "for urban redevelopment, prompting private investment in adjacent areas" (Royal Commission on the Future of the Toronto Waterfront, 1992, p. 186). The Waterfront Trail was thus a multidimensional strategy which combined environmental concerns with the provision of recreational uses and private sector involvement. As a foundation for development, 'green infrastructure' also included remediation of the waterfront's widely acknowledged soil and groundwater contamination and resolution of the flooding threat from the nearby Don River. These remnants of earlier modes of development, in which polluting land was an acceptable externality and channelizing the river created territorial certainty, were portrayed by the Commission as direct impediments to new - and increasingly indispensable - land uses. Highlighting these envIronmental problems was thus a crucial step in undermining industrial zoning, which stood in the way of new forms of development, and so the term 'green infrastructure' came to mean not only an interconnected system of parks and open spaces, but also environmental remediation and a process of engineered 'renaturalization'.

The Commission's recommendations for new land uses resulted in many legislative changes to the industrial zoning regime. The City of Toronto's Official Plan of 1992 opened a large section of the eastern waterfront to residential and mixed use development, parks, and public facilities. The industrial retention policy for the Port Lands was retained, although "new and relocating high employment industries [would] be encouraged to locate in this area" and the City allowed for parks and recreational uses, habitat protection, retail uses, and a "water's edge promenade" which was explicitly intended to increase "the attractiveness" of this area 
"to the public and to industry" (City of Toronto, 1992, s. 14.33-14.38; City of Toronto, 1994, s. 14.35-14.40).

\section{The private sector and the ecosystem approach}

The ecosystem approach allowed the Commission to consolidate an acceptable role for the private sector in waterfront development in two ways. First, the urgent need for 'green infrastructure' under newly prevailing conditions of public fiscal restraint necessitated finding "new and innovative financing techniques" (Royal Commission on the Future of the Toronto Waterfront, 1989c, p. 124), opening the door to private-sector investment. Second, the rescaling of the physical and conceptual territory of the waterfront - from waterfront lands to the entire bioregion, and from the political arena to "the interactions among ecological, social, economic, and political systems within the bioregion" (Royal Commission on the Future of the Toronto Waterfront, 1990, p. 46) - provided the conceptual space for the Commission to concede to the increasingly common ideological position that the public sector was ineffective, inefficient, and incapable of resolving pressing issues. In other words, the scale and scope of environmental degradation on a waterfront connected to a much broader collection of ecological processes meant that "governments alone cannot solve our environmental problems" (Royal Commission on the Future.of the Toronto Waterfront, 1990, p. 46) and thus the involvement of the private sector, which would supply "enterprise, initiative, and capability for investment and creativity" (Royal Commission on the Future of the Toronto Waterfront, 1992, p. 309), was required.

Moreover, the stakeholder roundtable model itself was a major avenue through which private sector interests were both welcomed and privileged. While the model was based on an egalitarian premise that "all partners should be at the table when plans are being made for the waterfront" (Barrett, 1991, p. 104), it suffered from a significant democratic deficit in that - like many other development planning processes - it did not recognise, accommodate, or attempt to ameliorate differential power relations (see Checkoway, 1994; Flyvbjerg, 2002; Friedmann, 1998; Harvey, 1996b; Neuman, 2000; Yiftachel, 1999 for criticisms of such approaches).

\section{A new vehicle for change: the waterfront regeneration trust}

As the Commission's mandate ended in 1992, the provincial government created a new agency - the Waterfront Regeneration Trust (the Trust) - to facilitate the Commission's implementation strategy. Also headed by David Crombie, the Trust reported to the Ontario Minister of Environment as a nonprofit agent of the Crown (Ontario, 1992) and explicitly adopted the Commission's ecosystem ap- proach in all aspects of its work (Barrett, 2000). While the Trust's activities during its seven year public mandate ${ }^{6}$ are too numerous to recount here in any detail, it is sufficient to highlight some aspects of its considerable influence over reshaping waterfront relations to address jurisdictional gridlock, industrial zoning, and public-private relations.

The Trust was constituted specifically, and in the ecosystem approach-based mode, as a co-ordinating body, and was given the ability to negotiate with other levels of government over waterfront development planning and projects (Ontario, 1992; Goldrick and Merrens, 1996, p. 227). As such, it provided a specifically-tailored institutional response to the problems standing in the way of waterfront development. Its continued use of the stakeholder roundtable model for decision making resulted in a number of jointly financed and managed development agreements between various waterfront municipalities and the provincial government, as well as between various combinations of community based groups, corporations, organizations, and public agencies. This was particularly true in its facilitation of construction of the Waterfront Trail, which became a catalytic 'clothesline' on which development projects were hung, and a physical and political incentive around which governments, community members, businesses, and groups and organizations of a variety of descriptions could coalesce in support of a common, nominally 'green' goal. As such, the Trust acted in many ways as a new model for jurisdictional co-operation, pursuing a strategy of 'progressive incrementalism' to creatively accommodate and facilitate a spatial response to economic change.

The Trust actively took steps to promote a wide variety of land uses for the waterfront, and through a long succession of reports, workshops, consultations, and planning processes consolidated the acceptability of ending exclusive industrial zoning. The Trust promoted these uses, including residential, "new industry" and parks and public space, as being necessary "to achieve [a] vision of the waterfront of the future" (Waterfront Regeneration Trust, 1995a, p. 74) that was, strategically, tinted a distinct shade of green. Dense residential developments were deemed necessary to alleviate urban sprawl. "New enterprises" including "television, film and communications, graphics, health research, and recycling industry, ...tourism, sports, trading and entertainment" were necessary to create supposedly non-polluting jobs (Waterfront Regeneration Trust, 1995a, p. 62). Uses promoting tourism, such as parks and recreational space, would also facilitate improved environmental quality and habi-

6 The Waterfront Regeneration Trust acted as a public agency between 1992 and 1999 and was converted thereafter, through a privatization effort undertaken by the Mike Harris Conservative provincial government, into a non-profit, non-governmental agency. 
tat restoration. The waterfront of the future would be a place to 'live, work, and play' with economic development - now declared an environmental panacea - given priority.

Just as important were the new technological and regulatory solutions proposed by the Trust to resolve soil and groundwater contamination and the flooding threat, allowing new land uses to be seen as both economically possible and politically acceptable. All in all, the Trust's work to overcome industrial zoning on the waterfront encouraged a new green flexibility and entrepreneurialism, demonstrating that "the goals of economic renewal, community well being and environmental health can be combined to promote redevelopment and job creation" (Waterfront Regeneration Trust, 1995b, p. i). Before long, the era of industrial hegemony on the waterfront would come to an end, and new era begun wherein the City of Toronto became an active promoter of new, more lucrative, and more competitively advantageous uses.

While the Trust continued to include the private sector in its planning processes and consultations, perhaps its most important contribution to transforming private-public relations on the waterfront came through a reconfiguration of these sectors' respective roles in infrastructure financing. Public sector investment in 'green infrastructure' such as parks and habitat restoration was encouraged for providing environmental benefits, but more importantly was presented as a strategic necessity for encouraging private sector investment in new development. And with environmental contamination a limiting factor, an entrenched 'polluter pays' principle (Waterfront Regeneration Trust, 1993, p. 59) was subverted through a strategic use of nature as a public good. The Trust put forward the position that, just as the compromising of nature's health through industrial production had been necessary for the production of society's wealth in the past, the improvement of nature's health would be required to produce continued prosperity in the future. As such, it would only be 'fair' for investor liability and private capital's environmental externalities to be paid for by government (Waterfront Regeneration Trust, 1993, p. 79).

Not only did the Trust demonstrate an increasing emphasis on providing economic opportunities for the private sector through public sector investment in environmental improvement, its work also revealed a growing concern with reconfiguring waterfront lands in order to meet the imperatives of the global economy. Reports call on governments to recognise the geographic consequences of global economic restructuring and to focus waterfront development on "value-added knowledge intensive activities" in order for the waterfront "to play its constructive role in positioning the Toronto region for the 21st century" (Waterfront Regeneration Trust, 1993, pp. 5-6). Development of the waterfront
- indeed, the waterfront itself - became an instrument for participation in and the furtherance of the global imperative. Reconciling jurisdictional authority, reconfiguring land use, and realigning private-public sector relations increasingly became the means by which the waterfront would be made to both respond to and foster the global economy's reach.

Overall, the Waterfront Trust's mandate can be characterised as the period within which the imperatives of the economy, and particularly those of the global economy, eclipsed the environmentalism inherent in the ecosystem approach (see Desfor and Keil, 2004; Keil and Desfor, 2003; Keil and Graham, 1998). But constructing the green infrastructure necessary to facilitate development was prohibitively expensive and the Waterfront Trail was proving insufficient to stimulate a comprehensive transformation of Toronto's Central Waterfront. Crombie and other principals of the Trust determined that a larger-scale project would be necessary. They made a conscious decision to 'go big' and launched another bid to host an Olympic Games.

\section{Going big: a mega-green waterfront}

Having learned from the Trust's ecosystem approach-based successes that a broad-based, inclusive and consultative strategy was critical to success in Toronto, the Trust began a series of one-on-one and small group discussions to gauge and consolidate support, at least one year before news of the proposed 2008 bid became public. Indeed, using the various connections that had been built through the work of both the Royal Commission and the Trust, Crombie and his key Trust staffers met with a seemingly unending variety of groups to identify and address their concerns. This multi-sectoral, community-based strategy, which the 1996 bid eschewed, secured much-needed support from across a wide range of sectors. Many groups and organizations that had criticised the 1996 bid were appeased by promises of jobs in the construction and tourism sectors and by the promise of increased revenues that would accrue to the city, which had been fiscally hamstrung by a three-year property tax freeze. In addition, a set of 'Olympic Principles' - required by City Council in return for its endorsement and financial support (City of Toronto, 2000c) - promised a plethora of social benefits to various local communities and organizations.

By the late 1990s, political conditions across all scales of the Canadian state had shifted such that the focus on fiscal efficiency, program rationalization, and debt reduction was joined by a growing preoccupation with improving economic integration at the global scale (Macdonald, 1997). Public-private partnerships had become the answer to supposed government inefficiency, the promotion of sectoral 
agglomeration was gaining steam, and cities were increasingly recognised as primary generators of new economic activity (Bradford, 2003). The City of Toronto's own Economic Development Strategy, adopted in July 2000, insisted that "cities have emerged as the building blocks of a global economy" and that, in order to adequately compete with its competitor cities, Toronto would benefit by adopting such neoliberal tools as the so-called "innovative new financing instruments" along with "harnessing the power of public, private and voluntary sector partnerships" and adopting "new roles in economic development" such as "entrepreneurship" and "risk financing" (City of Toronto, 2000c, p. 6, pp. 20-21). Toronto was poised to be recognized as the province's and nation's economic engine in the new global economy.

As such, the promise of a 'world class' event like the Olympic Games was a draw for governments increasingly focusing their policies around global interurban competitiveness. The global scale of the Olympics - fostered by an increasingly economically focused Trust pursuing the ecosystem approach to development - thus provided yet another step toward resolving jurisdictional fragmentation. Additionally, however, the mega-event strategy became the consolidating moment for the land-use plans that had already been made by the Commission and the Trust. The catalytic impact of the bid would prove to be the last step in the long process of changing waterfront zoning regulations to allow for 21 st-century economic uses.

In November 1999, Canadian Prime Minister Chretien, Ontario Premier Harris and Toronto Mayor Lastman gathered on the waterfront to announce "a grand, 10-year plan for massive redevelopment of the city's 46-kilometre waterfront" (Moloney and DeMara, 1999). The plan recommended an integrated program of green infrastructure elements including "a 30- to 50-m wide 'greenway'" along the entire waterfront, renaturalizing the mouth of the Don River, and making the waterfront an "area that nurtures wildlife, restores and creates natural habitats, and provides water that is clean and healthy" (City of Toronto, 1999a, p. 5). In the spirit of the ecosystem approach, this green infrastructure also included public amenities such as "bandshells, a new aquarium, a new museum," affordable housing, and a "home for Toronto's growing and internationally-competitive 'imagination industries' such as new media, film, animation, and digital creations" and "leading-edge environmental industries" (City of Toronto, 1999a, p. 17).

Provision of these green infrastructural elements was portrayed as the catalyst of an economic renaissance, and the "spectacular" places and spaces that would be built on the waterfront would "create the synergies that will draw even more jobs and investment to Toronto" (City of Toronto, 1999a, p. 3) and "add to Toronto's allure as a tourist destina- tion" (City of Toronto, 1999a, p. 21). The document exhorted Toronto to respond to the exigencies of the global economy and positioned a revitalized waterfront as the optimal location to engage the "highly competitive world where entrepreneurs, skilled workers and innovative companies gravitate to cities that offer the best quality of life" (City of Toronto, 1999a, p. 3).

While the waterfront development plan was perhaps disingenuously positioned not as foundational to the Olympic bid but rather as a distinct project "big enough to embrace" an Olympic Games (City of Toronto, 1999a, p. 3), the report made clear their interrelated political economy. The provision of green.infrastructure held the potential to provide for the requirements of both the Olympic bid as well as future development. But since the International Olympic Committee's financing rules required longer-lasting, city-building expenditures to be financed by "the public authorities or the private sector" (International Olympic Committee, 2000), the massive costs of green infrastructure would have to be found elsewhere. In a ground-breaking statement, the report pledged public-sector funds to create these new opportunities for land-based capital accumulation:

Strategic public investment in cleaning up contaminated sites and improving public spaces, primes the pump and creates new opportunities for investment. It creates a "virtuous cycle" in which new business generates more property taxes, more property taxes lead to better public facilities, better public facilities attract more investment and more investment creates more jobs. (City of Toronto, 1999a, p. 7).

Not only did the public assumption of such investment allow the private sector to externalise the massive costs of remediation, which only a few years before were considered its rightful responsibility, it also transformed a Keynesian-based rationale for public sector spending into support for a speculative and entrepreneurial 'trickle-down' neoliberal economic and social policy.

The lines between TO-Bid, the private corporation which took over promotion of the Olympic bid from the Trust, and the three levels of government began to blur. TO-Bid recruited Robert Fung, a successful investment banker, corporate financier, mining company director and long-time Liberal Party member, to assist in creating both the Olympic and waterfront development budgets. Simultaneously, Lastman announced that Fung had been appointed to head a "citizen task force" (Moloney and DeMara, 1999) that would report to Council on project costs, timing, and "opportunities for government and private sector involvement" (City of Toronto, 1999b). The Fung Task Force was made up almost exclusively of private-sector businesspeopIe, many of whom were directly connected to the Olympic bid. Although it held no public consulta- 
tions, the Task Force sought the advice of senior real estate and finance executives, corporate strategists, and urban design, engineering, and production consultants (Toronto Waterfront Revitalization Task Force, 2000). In early 2000, the Task Force produced its report, which outlined a three-part 'strategic business plan' for waterfront development.

The Task Force's 'development concept,' or, more traditionally, its land-use plan, provided for all of the uses that had been accommodated in the Royal Commission's ecosystem approach. The 'financial concept' called on governments to provide much of the $\$ 5.2$ billion investment necessary to accommodate the project's infrastructural and environmental remediation needs. And the 'operational concept' provided a market-focused institutional remedy to the problem of jurisdiction, calling for the creation of a "development corporation" that would "operate in a business model" offering "investors or partners a greatly simplified planning process" with an "efficient and action-orientated" governance structure (Toronto Waterfront Revitalization Task Force, 2000, p. 61). The Task Force report thus consolidated the work of the Royal Commission and the Waterfront Trust in a development model incorporating the operational practices of the private sector and functioning in accord with the logic of capital.

The Task Force report was subsequently approved by Council (City of Toronto, 2000a) and, in October 2000 , the 'three amigos, 7 converged once again on the waterfront to announce a joint investment of $\$ 1.5$ billion in "major infrastructure development; a thorough environmental clean-up of the area; and the creation of greenspaces at key points along the waterfront" (Ontario, 2000).

The Olympic bid thus not only transformed government policy in favour of waterfront development, as the Trust had desired, it also forced governments into financing environmental remediation and infrastructure provision. This was, from the beginning, one of the main focuses of the Olympic effort, not only because of the longer-term benefits to development interests, but also, more strategically in the short term, because environmental initiatives were one of the International Olympic Committee's three Olympic 'pillars', along with sport and culture. Crombie was often quoted as saying that cleaning up the waterfront was important for the bid in that "we get points for stuff like this" (in McAndrew, 2000). And, with infrastructure provision having taken on an environmentally-tinged hue, public spending on both could be rationalized within the rubric of an environmental fix.

The politics of the Olympic bid thus saw two mutually reinforcing, scaled strategies at play. The global

\footnotetext{
7 Chretien, Harris and Lastman were dubbed the 'three amigos' by the press due to the uncharacteristic fraternity they displayed at waterfront announcements, during which they jokingly referred to one another as 'my buddy' and 'my new best friend'.
}

event promised the potential for economic and political benefit for all levels of government, and government investment in the waterfront's local green infrastructure made the globally-focused Olympic bid palatable for local politicians and residents. As such, a 'Green Olympics', as the 2008 Bid became known, was a forceful strategy to facilitate waterfront development. In Toronto, as in many other cities, the mega-event strategy both consolidated the growth coalition and operationalised its ambitions, permitting "the powerful interests in cities to attach their agendas to the Olympic process, creating the perfect policy mechanism for ensuring a growth agenda" (Andranovich et aI., 2001, p. 127). But in Toronto, this policy mechanism was decidedly green, an outgrowth of the Royal Commission's ecosystem approach to waterfront development.

The October 2000 announcement also committed governments to the Task Force's corporate development model. With one month to spare before the IOC's decision would be announced, Council voted to support the creation of the Toronto Waterfront Revitalization Corporation, the vehicle through which public-sector financing could be taken off the books of the Olympic bid. At the same time, the Fung Task Force report was being "translated" into the City's Central Waterfront Secondary Plan by many of the same planners, urban designers, and urban strategists who had consulted on the Task Force (Urban Strategies, 2005). Thus the plan for the Olympics, which the Task Force was in effect intended to produce, also became the City's waterfront plan. The roles of the public and private sectors in planning for and developing the waterfront became deeply intertwined. As TO-Bid's Vice-President said, "What's Olympic work and what's waterfront work? This is all in furtherance of waterfront issues" (in Sewell, 2001).

\section{Bid dies: vision endures}

The Olympic bid and its associated waterfront plan was the vehicle through which Toronto could be repositioned on the global stage and thus become a 'world class' city. Policy and legislative documents resulting from the Olympic bid's work made explicit comparisons between Toronto and other-international cities, such as London, Barcelona, Baltimore, and New York, which were said to be "reaping the benefits" (Moloney and DeMara, 1999) of their own waterfront development initiatives. While many of these cities have experienced negative social, environmental, and economic impacts resulting from these projects (Basset et aI., 2002; Florio and Brownill, 2000; Moulaert et aI., 2003; Sandercock and Dovey, 2002; Swyngedouw et aI., 2002), the economic benefits to business, the catalytic 'sparking' of external investment, the improvement of urban aesthetics, the luring of well-heeled tourist dollars, and the construction of a cosmopolitan, vibrant, and urbane aura that were said to have arisen from their 
reconfigured waterfronts were lauded as models for Toronto and proclaimed as the ultimate answer to Toronto's longstanding waterfront problem. Toronto was to reconfigure itself into an entrepreneurial entity by building "the greatest waterfront in the world" (City of Toronto, 2000b) using a development model based on speculative investment in green infrastructure.

With the hyperbolic rhetoric at a fever pitch, in July 2001 the International Olympic Committee announced that Beijing, and not Toronto, would host the 2008 Olympics. Despite this loss, described by Fung as "a great disappointment, but not a tragedy" (Fung, 2001), and despite many ensuing hurdles, the waterfront revitalization plan arising from the Olympic bid continues to be pursued by the Toronto Waterfront Revitalization Corporation.

\section{Conclusions: a new waterfront development paradigm}

This paper illustrates in detail one chapter in the ongoing coupling of nature and society in the politics of urban development in Toronto. While I do not argue or want to imply an instrumentalist correlation between the activities of the Royal Commission and the formation of the TWRC, this paper highlights the significant notion that the variety of activities undertaken under particular local conditions and influenced by extra-local economic and political transitions are important in the construction of the urban landscape, and in particular the capitalist urban landscape. In so doing, this paper demonstrates, in a contemporary context, that "what is happening along the urban waterfront is a reflection of changes in the city itself and, more importantly, of the changing political economy in which the city is located" (Desfor et aI., 1989, p. 499).

The analysis presented in this paper suggests two primary conclusions. First, while the environmentdevelopment conflation demonstrated in the 'ecosystem approach' promises to improve environmental conditions on the waterfront, it also promises to transform its frontier-like terrain of availability into a beachhead of possibility for large-scale capital investment. The 'ecosystem approach' to planning, a powerful paradigm in which a variety of conflicting groups, ideological positions, political imperatives, environmental concerns, and social values were reconciled, resolved a variety of historic problems that were impeding the progress of waterfront development. The wide-ranging consultations that both led to and followed from its adoption were instrumental in creating support for growth and significantly improved the conditions within which waterfront development could support the accumulation of capital, providing the political climate necessary for continued growth under changing macro-economic conditions. And while development was effectively stalled for many years pending completion of the work of the Royal
Commission, its longer-term transformation of both legislative and conceptual conditions necessary for development provided the conditions within which a larger-scale transformation - currently being pursued through the Toronto Waterfront Revitalization Corporation - could become possible.

Second, the prevalence of extra-governmental bodies and processes in the reconfiguration of the legislative conditions under which large-scale, globally-focused waterfront development could be undertaken in Toronto demonstrates not only the institutional flexibility accompanying the ecosystem approach, but also the increasingly secondary role that urban planning has played in encouraging waterfront change. Indeed, as is demonstrated in the TO-Bid/City planning exercise, the City of Toronto's planning function has largely become reactive rather than proactive, and largely responsive to the vagaries and desires of private interests.

Goldrick and Merrens (1996) note that, despite its "bioregional rhetoric" (237) the Royal Commission did not, in fact, adequately address itself to the promise of the ecosystem approach but instead settled for a variety of institutional reforms that were unable to achieve its own stated goals. As the past ten years have demonstrated, however, the ecosystem approach and the method by which it was operationalized by the Royal Commission and successive bodies - that is, as a conceptual device and political tool - not only facilitated the formation of a new waterfront development paradigm that explicitly privileges economic growth over environmental concerns, but also restructured the processes and power relations of waterfront planning in a manner that privileges private interests. As such, the ecosystem approach of the Royal Commission on the Future of the Toronto Waterfront can best be understood not only as "'a mode of social regulation' for facilitating economic growth" (Desfor, 1993, p. 179) but also as an example of the kind of "roll out" neoliberalism that has reshaped urban social relations in Ontario (Peck and Tickell, 2002; Keil, 2002).

\section{Acknowledgements}

The author would like to acknowledge the editors of this special issue, the journal editor, and the two anonymous reviewers for the many prescient and helpful comments made on this paper.

\section{References}

Adams, M and Neuman, K (2006) It's not easy being green. The Globe and Mail, October 20, p. A21.

Andranovich, G, Burbank, M J and Heying, CH (2001) Olympic cities: lessons learned from mega-event politics. Journal of Urban Affairs 23(2), 113-131.

Armstrong, J (1992) Waterfront plan unveiled, 'Jurisdictional gridlock' must end, Crombie says. The Toronto Star, May 15, p. A7.

Barrett, S (2000) A Decade ofRegeneration: Realizing a Vision for Lake Ontario. Waterfront Regeneration Trust, Toronto. 
Barrett, S (1991) Pathways: Towards an Ecosystem Approach. A Report of Phases I and 11 of an Environmental Audit of Toronto's East Bayfront and Port Industrial Area. Minister of Supply and Services Canada, Ottawa. April.

Basset, K, Griffiths, R and Smith, I (2002) Testing governance: partnerships, planning and conflict in waterfront regeneration. Urban Studies 39(10), 1757-1775.

Bradford, N (2003) Public-Private partnership? Shifting paradigms of economic governance in Ontario. Canadian Journal of Political Science 36(5), 1005-1033.

Bunce, S (2004) The emergence of 'smart growth' intensification in Toronto: environment and economy in the new official plan. Local Environment 9(2), 177-191.

Canada (2000) Prime Minister Announces \$500 Million for Toronto 2008 Olympic Bid and Waterfront Revitalization. Media Release, October 20.

Checkoway, B (1994) Paul Davidoff and advocacy planning in retrospect. Journal of the American Planning Association 60(2), 139-143.

City of Toronto (1992). Draft Official Plan Part I Consolidation: CityPlan Final Recommendations. City of Toronto Planning and Development Department, Toronto.

City of Toronto (1994). CityPlan: City of Toronto Official Plan. City of Toronto, Toronto.

City of Toronto (1999a). Our Toronto Waterfront: The Wave of the Future! City of Toronto, Toronto.

City of Toronto (1999b). Bold new vision announced for city waterfront. Media release 3 November.

City of Toronto (2000a). Toronto's Waterfront Development "A Reality" Mayor Lastman announced $\$ 1.5$ billion to start huge project. Media Release 20 October.

City of Toronto (2000b). Minutes of the Council of the City of Toronto, Tuesday August 1 to Friday August 4 2000. City of Toronto, Toronto.

City of Toronto (2000c). Toronto's 2008 Olympic and Paralympic Games Bid: Toronto Staff Report to Council. Toronto: Commissioner of Economic Development, Culture and Tourism, 11 February.

City of Toronto (2000d). Toronto Economic Development Strategy. City of Toronto Economic Development, Toronto.

Crook, F (1983) Harbourfront denies wasting taxpayers' money. The Toronto Star, December 14, p. A6.

Desfor, G, Goldrick, M and Merrens, R (1989) A political economy of the water-frontier: planning and development in Toronto. Geoforum 20(4), 486-501.

Desfor, G (1993) Restructuring the Toronto Harbour Commission: land politics on the Toronto waterfront. Journal of Transport Geography 1(3), 167-181.

Desfor, G and Keil, R (2004) Nature and the City: Making Environmental Policy in Toronto and Los Angeles. University of Arizona Press, Tucson.

Florio, Sand Brownill, S (2000) Whatever happened to criticism? Interpreting the London Docklands development corporation's obituary. City 4(1), 53-64.

Flyvbjerg, B (2002) Bringing power to planning research: one researcher's praxis story. Journal of Planning Education and Research 21, 353-366.

Friedmann, J (1998) Planning theory revisited. European Planning Studies 6(3), 245-253.

Fung, R (2001) New waterfront will be lasting legacy: although the 2008 Olympic Games will not be held in Toronto, the bid lit spark for project that will enhance our city. The Toronto Star, July 16, p. A17.

Goldrick, M and Merrens, R (1996) Toronto: searching for a new environmental planning paradigm. In City, Capital and Water, P Malone (ed.). Routledge, New York.

Grant, J (2002) Mixed use in theory and practice: Canadian experience with implementing a planning principle. Journal of the American Planning Association 68(1), 71-83.

Greenberg, K (1996) Toronto: The urban waterfront as a terrain of availability. In City, Capital and Water, P Malone (ed.), pp. 95-218. Routledge, New York.
Hartmann, FM., (1998). Nature in the City: Urban Ecological Politics in Toronto. York University, Toronto, Unpublished Ph.D. Dissertation.

Harvey, D (1996a) Justice, Nature \& the Geography of Difference. Blackwell Publishers, Cambridge, MA.

Harvey, D (1996b) On planning the ideology of planning. In Readings in Planning Theory, S Campbell and S Fainstein (eds.), pp. 176-197. Blackwell Publishers.

Hodge, G and Robinson, I M (2001) Planning Canadian Regions. UBC Press, Vancouver.

Hodge, G. (2003). Planning Canadian Communities, 4th Edition. Nelson, Toronto.

International Olympic Committee, (2000). Questionnaire for Cities Applying to become Candidate Cities to host the Games of the XXIX Olympiad in 2008. International Olympic Committee, Lausanne, Switzerland. <multimedia.olympic.org/ pdf/en_report_288.pdf> (24.05.2005).

Keil, R (2002) 'Common-sense' neoliberalism: progressive-conservative urbanism in Toronto, Canada. In Spaces of Neoliberalism, N Brenner and N Theodore (eds.), pp. 230-253. Blackwell Publishers, Oxford.

Keil, Rand Boudreau, J A (2006) Metropolitics and metabolics: rolling out environmentalism in Toronto. In In the Nature of Cities: Urban Political Ecology and the Politics of Urban Metabolism, N Heynen, M Kaika and E Swyngedouw (eds.), pp. 41-62. Routledge, Abingdon.

Keil, Rand Desfor, G (2003) Ecological modernisation in Los Angeles and Toronto. Local Environment 8(1), 27-44.

Keil, Rand Graham, J (1998) Reasserting nature: constructing urban environments after Fordism. In Remaking Reality: Nature at the Millennium, B Braun and N Castree (eds.), pp. 100-125. Routledge, London and New York.

Kipfer, Sand Keil, R (2002) Toronto Inc? Planning the competitive city in the New Toronto. Antipode 34(2), 227-264.

Kipfer, Sand Keil, R (2000) Still planning to be different? Toronto at the turn of the millennium. DISP 140, 28-36.

Krajnc, A (2000) Wither Ontario's environment? neo-conservatism and the decline of the environment ministry. Canadian Public Policy 26(1), 111-127.

Macdonald, L (1997) Going global: the politics of Canada's foreign economic relations. In Understanding Canada: Building on the New Canadian Political Economy, W Clement (ed.), pp. 72-196. McGill-Queen's University Press, Montreal \& Kingston.

Malone, P (1997) City, Capital and Water. Routledge, New York.

McAndrew, B (2000) Arsenic and old grease: an olympian challenge. The Toronto Star, March 18, pp. B1-B4.

McKenzie, J I (2002) Environmental Politics in Canada: Managing the commons into the twenty-first century. Oxford University Press, Don Mills.

McLaughlin, SG (1987) Federal Land Management in the Toronto Region: A Reportfor Ministerial Consideration on the Effective Management of Federal Lands in the Region of Metropolitan Toronto. Stephen G. McLaughlin Consultants, Toronto.

Moloney, P and DeMara, B (1999) Plan for waterfront called 'breathtaking': ambitious scheme will require 'multi-billions' of dollars. The Toronto Star, November 4, p. AI.

Moulaert, F, Rodriguez, A and Swyngedouw, E (eds.) (2003) The Globalized City: Economic Restructuring and Social Polarization in European Cities. Oxford University Press, Oxford.

Neuman, M (2000) Communicate This! Does consensus lead to advocacy and pluralism? Journal of Planning Education and Research 19(4), 343-350.

Ontario (1992). Waterfront Regeneration Trust Agency Act, 1992. S.O. 1992, c.2.

Ontario (1996). Changes to Ontario's planning process. Media Release, 22 May 1996.

Ontario (2000). \$1.5 billion for Toronto waterfront re-development an investment in the future: Harris, Media Release, 20 October.

Peck, J and Tickell, A (2002) Neoliberalizing Space. In Spaces of Neoliberalism, N Brenner and N Theodore (eds.), pp. 33-57. Blackwell Publishers, Oxford. 
Reid, R, Lockhart, Rand Woodburn, B (1989) A Green Strategy for the Greater Toronto Waterfront: Background and Issues. Royal Commission on the Future of the Toronto Waterfront, Toronto.

Royal Commission on the Future of the Toronto Waterfront (1989a). Interim Report: Summer 1989. Minister of Supply and Services Canada, Ottawa.

Royal Commission on the Future of the Toronto Waterfront (1989b). Parks, pleasures, and public amenities: Report of the parks, pleasures, and public amenities work group. Minister of Supply and Services Canada, Ottawa.

Royal Commission on the Future of the Toronto Waterfront (1989c). Jobs, opportunities and economic growth: Report of the jobs, opportunities and economic growth work group to the Royal Commission on the Future of the Toronto Waterfront. Minister of Supply and Services Canada, Ottawa.

Royal Commission on the Future of the Toronto Waterfront (1990). Watershed: Interim Report: August 1990. Minister of Supply and Services Canada, Ottawa.

Royal Commission on the Future of the Toronto Waterfront (1992). Regeneration: Toronto's waterfront and the sustainable city: Final report. Minister of Supply and Services Canada, Ottawa.

Sandercock, Land Dovey, K (2002) Pleasure, politics, and the 'public interest': Melbourne's riverscape revitalization. Journal of the American Planning Association 68(2), 151-164.

Savoie, D (1994) Thatcher, Reagan, Mulroney: in search of a new bureaucracy. University of Toronto Press, Toronto.

Sewell, J (2001) Is the city bankrolling the Olympic bid? Eye, February I.

Suzuki, D (1992) Toronto's 'ecosystem approach' generates hope. The Toronto Star August 29, p. D6.

Swyngedouw, E, Moulaert, F and Rodriguez, A (2002) Neoliberal urbanization in Europe: large-scale urban development projects and the new urban policy. In Spaces of Neoliberalism, N
Brenner and N Theodore (eds.), pp. 195-229. Blackwell Publishers, Oxford.

Swyngedouw, E, Heynen, F and Kaika, M (2005) In the Nature of Cities, Urban Political Ecology and the Politics of Urban Metabolism. Routledge.

Toronto Harbour Commissioners (1989). Port of Toronto News $36(1)$.

Toronto Harbour Commissioners (1992). Port of Toronto News $39(2)$.

Toronto Waterfront Revitalization Task Force (2000). Our Toronto Waterfront: Gateway to the New Canada. Toronto Waterfront Revitalization Task Force, Toronto.

Toronto Waterfront Revitalization Corporation (2002) The Development Plan and Business Strategy. Toronto Waterfront Revitalization Corporation, Toronto.

Urban Strategies (2005). Toronto Waterfront Plan. <www.urbanstrategies.com/projects/proj_b3.html> (24.06.2005).

Valpy, M (1990) Waterfront report heady stuff. The Globe and Mail, September 14, p. A10.

Waterfront Regeneration Trust (1995a). Lake Ontario Greenway Strategy. Waterfront Regeneration Trust, Toronto, May.

Waterfront Regeneration Trust (1995b). The West Don Lands. Waterfront Regeneration Trust, Toronto, December.

Waterfront Regeneration Trust., (1993). Lower don lands site remediation: challenges \& opportunities. In Workshop Proceedings, Waterfront Regeneration Trust, Toronto, May 25 and 26, 1993.

While, A, Jonas, A E G and Gibbs, D (2004) The environment and the entrepreneurial city: searching for the urban 'sustainability fix' in Manchester and Leeds. International Journal of Urban and Regional Research 28(3), 549-569.

Yiftachel, 0 (1999) Planning theory at a crossroad: the third Oxford conference. Journal of Planning Education and Research 18(3), 267-269. 